Note

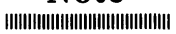

\title{
Effect of Ca-DTPA and Zn-DTPA on Essential Metal Contents in the Fetal Liver of Mice ${ }^{\dagger}$
}

\author{
Itaru Sato, Naonori Matsusaka, Shuji Tsuda, Haruo Kobayashi, Koichiro Sera*, \\ Shoji FutatsugawA** and Yoshikazu NishimURA*** \\ Faculty of Agriculture, Iwate University \\ 3-18-8, Ueda, Morioka-shi 020, Japan \\ ${ }^{*}$ Cyclotron Research Center, Iwate Medical University \\ 348, Tomegamori, Takizawa-mura, Iwate-gun, Iwate Pref. 020-01, Japan \\ ${ }^{* *}$ Nishina Memorial Cyclotron Center, Japan Radioisotope Association \\ 348, Tomegamori, Takizawa-mura, Iwate-gun, Iwate Pref. 020-01, Japan \\ ***National Institute of Radiological Sciences \\ 4-9-1, Anagawa, Inage-ku, Chiba-shi 263, Japan
}

Received February 18, 1997

\begin{abstract}
Ca-DTPA or Zn-DTPA was injected subcutaneously to pregnant mice once a day for 5 consecutive days from day 13 to 17 of gestation. Maternal and fetal livers were collected 20 hours after the final injection of DTPA, and essential metal contents in the liver samples were determined by PIXE.

Both $\mathrm{Ca}-D T P A$ and $\mathrm{Zn}-D T P A$ did not affect essential metal contents in the maternal liver, but Ca-DTPA significantly decreased copper and zinc contents in the fetal liver to $2 / 3$ and $1 / 2$ of the control value, respectively. $\mathrm{Zn}-D T P A$ did not affect fetal zinc content, but it decreased that of copper. It could not be determined whether DTPA affected fetal manganese content because the fetal liver contained no detectable amount of manganese.
\end{abstract}

Key Words : DTPA, essential metal, fetus, liver, PIXE, mouse

\section{Introduction}

In case internal contamination with radionuclides happens, surgical treatments such as resection of the contaminated skin and/or administration of emetics or purgatives should be done as

\footnotetext{
† マゥス胎児の肝臟内必須金属含量に及ぼす $\mathrm{Ca}-$ DTPA およびZn-DTPA の影響。佐藤 至, 松坂 尚典, 津田修治, 小林晴男, 世良耕一郎*, 二ッ川 章二**, 西村義一*** : 岩手大学農学部, 020 盛岡 市上田 3-18-8, *岩手医科大学サイクロトロンセ ンター, 020-01 岩手県岩手郡滝沢村留ヶ森 348, **日本アイソトープ協会仁科記念サイクロトロン センター, 020-01 岩手県岩手郡滝沢村留ヶ森 $348, * * *$ 放射線医学総合研究所, 263 千葉市稲毛 区穴川 4-9-1
}

soon as possible in order to decrease transfer of the radionuclides to the systemic circulation ${ }^{1}$. Several eliminants are also used for enhancing the excretion of incorporated radionuclides from the body. A chelating agent DTPA (diethylenetriaminepentaacetic acid) combines with radioactive metals and removes them via the kidneys ${ }^{2}$. But this chelating agent has an ability to combine with certain essential metals. In our previous studies, Ca-DTPA increased the urinary loss of manganese, copper and zinc, and induced transitory hypozincemia ${ }^{3), 4)}$. Although Zn-DTPA did not affect any essential metal concentration in the plasma, increased urinary loss of copper was 
observed $^{4,5)}$. On the other hand, Ca-DTPA induces fetal injuries such as abortion, fetal death and malformation when injected into pregnant animals ${ }^{6,7)}$. The cause of these toxic effects of $\mathrm{Ca}^{-}$ DTPA is considered an essential metal depletion in fetuses ${ }^{8), 9)}$. Nevertheless effect of DTPA on essential metals has not been reported in fetuses. In the present experiment, therefore, essential metal contents in the fetal liver were measured in pregnant mice which had been treated with $\mathrm{Ca}^{-}$ DTPA or Zn-DTPA.

\section{Materials and Methods}

Adult female ICR mice, 12-14 weeks old, were maintained on a commercial diet (MF, Oriental Yeast) and tap water in a room controlled at $23^{\circ} \mathrm{C}$. They were mated overnight, and gestational day was defined as day 0 when a vaginal plug was present. Fifteen pregnant mice were divided into 3 groups of 5 mice each, and 2 groups of them were given subcutaneous injections of $\mathrm{Ca}^{-}$ DTPA or Zn-DTPA once a day for 5 consecutive days from day 13 to 17 of gestation. The administered dose of Ca-DTPA and Zn-DTPA was $300 \mu \mathrm{mol} / \mathrm{kg} /$ day, which was 10 times as much as the recommended daily dose for humans. The other group was used as controls without any treatment.

Twenty hours after the final injection (day 18 of gestation), the animals were killed under ether anesthesia, and their liver and fetuses were excised and weighed. Five arbitrary fetuses of a litter were dissected to collect the fetal liver. About $100 \mathrm{mg}$ of each liver sample was dissolved in $1 \mathrm{ml}$ of $10 \mathrm{~N}$ nitric acid, and indium chloride solution was added to the samples as an internal standard (100 or $200 \mu \mathrm{g}$-In/g tissue). The maternal and fetal liver samples were analyzed by PIXE (particle induced X-ray emission), and essential metal contents in the samples were determined by analyzing X-ray spectra using SAPIX ${ }^{10}$.

\section{Results}

Table 1 shows calcium, manganese, iron, copper, zinc, and selenium contents in the liver samples. Calcium, iron, zinc and selenium contents in the fetal liver were similar to those in the maternal liver, whereas fetal copper content was much greater than maternal one. Fetal liver contained no detectable amount of manganese. Although both $\mathrm{Ca}^{-}$and $\mathrm{Zn}$-DTPA did not affect these 6 metal contents in the maternal liver, $\mathrm{Ca}^{-}$ DTPA decreased copper and zinc contents in the fetal liver to $70 \%$ and $50 \%$ of the control value, respectively. Zn-DTPA decreased copper content in the fetal liver, but it did not alter that of zinc.

Table 2 shows the number of fetuses and their body weight. There were no significant differ-

Table 1 Essential metal concentrations in the mouse liver on gestational day 18 ( $\mu \mathrm{g} / \mathrm{g}$ wet tissue)

\begin{tabular}{crrrrrrr}
\hline & \multicolumn{3}{c}{ Maternal liver } & & \multicolumn{3}{c}{ Fetal liver } \\
\cline { 2 - 4 } \cline { 7 - 8 } & \multicolumn{1}{c}{ Control } & Ca-DTPA & Zn-DTPA & & Control & Ca-DTPA & Zn-DTPA \\
\hline $\mathrm{Ca}$ & $49.9 \pm 6.7$ & $52.3 \pm 7.1$ & $45.5 \pm 10.0$ & & $52.3 \pm 8.1$ & $54.6 \pm 6.2$ & $58.5 \pm 9.0$ \\
$\mathrm{Mn}$ & $1.6 \pm 0.4$ & $1.4 \pm 0.4$ & $1.3 \pm 0.3$ & & ND & ND & ND \\
$\mathrm{Fe}$ & $64.2 \pm 24.6$ & $46.3 \pm 8.8$ & $65.4 \pm 21.6$ & & $86.6 \pm 22.1$ & $72.0 \pm 10.9$ & $85.0 \pm 19.8$ \\
$\mathrm{Cu}$ & $4.6 \pm 0.8$ & $4.2 \pm 0.5$ & $3.8 \pm 0.3$ & & $26.1 \pm 6.7$ & $18.6 \pm 3.0^{*}$ & $14.1 \pm 2.9^{*}$ \\
$\mathrm{Zn}$ & $33.7 \pm 5.2$ & $33.0 \pm 1.2$ & $31.3 \pm 2.5$ & & $32.8 \pm 5.0$ & $16.1 \pm 1.6^{*}$ & $27.9 \pm 2.1$ \\
$\mathrm{Se}$ & $0.9 \pm 0.1$ & $0.9 \pm 0.0$ & $0.6 \pm 0.2$ & & $0.6 \pm 0.1$ & $0.6 \pm 0.1$ & $0.4 \pm 0.1$ \\
\hline
\end{tabular}

Mean $\pm S D, *$ Significantly different from control $(\mathrm{p}<0.05)$ 
Table 2 Number of fetuses and their weight

\begin{tabular}{lccc}
\hline & $\begin{array}{c}\text { Number } \\
\text { (a litter) }\end{array}$ & $\begin{array}{c}\text { Weight } \\
\text { (g/fetus) }\end{array}$ & $\begin{array}{c}\text { Total } \\
\text { weight } \\
(\mathrm{g} / \text { litter })\end{array}$ \\
\hline Control & $13.8 \pm 1.3$ & $1.43 \pm 0.13$ & $19.6 \pm 1.5$ \\
Ca-DTPA & $14.6 \pm 2.1$ & $1.29 \pm 0.14$ & $18.6 \pm 1.3$ \\
Zn-DTPA & $11.6 \pm 1.5$ & $1.45 \pm 0.18$ & $16.9 \pm 2.7$ \\
\hline
\end{tabular}

Mean \pm SD

ences between the control and DTPA-treated groups. As for fetal abnormalities, a case of cerebral hernia and a case of fetal death were recognized with naked eyes in the control and $\mathrm{Ca}^{-}$ DTPA group, respectively.

\section{Discussion}

The results of this experiment showed that $\mathrm{Ca}^{-}$ DTPA decreased zinc and copper contents in the fetal liver without inducing zinc depletion in the maternal liver when injected into pregnant mice. As DTPA can not penetrate placental barrier ${ }^{11}$, the fetal zinc depletion is due to decrease of placental transfer of zinc. Because Ca-DTPA is less stable than $\mathrm{Mn}^{-}, \mathrm{Cu}^{-}$and $\mathrm{Zn}-\mathrm{DTPA}^{12)}, \mathrm{Ca}^{-}$ DTPA may dissociate its calcium, and combine with manganese, copper and/or zinc in the body to form more stable chelates. In our previous studies, Ca-DTPA markedly increased the urinary excretion of zinc, and caused transitory hypozincemia in rats $^{3), 4)}$. Therefore, the fetal zinc depletion induced by Ca-DTPA is considered to be caused by maternal hypozincemia. In adults, Ca-DTPA-induced urinary loss of zinc, which was estimated to be $1.1 \mathrm{mg} / 30 \mu \mathrm{mol} \mathrm{Ca-DTPA}{ }^{3)}$ can be compensated by homeostatic mechanisms such as increased intestinal absorption and controlled excretion of zinc. But fetuses are entirely dependent on the maternal blood for their nutrition, so that maternal hypozincemia will easily induce fetal zinc deficiency. Zinc is essential for many metaloenzymes such as RNA polymerase and superoxide dismutase, and the lack of zinc induces growth retardation, skeletal disorders, dermatitis, diarrhea, and immunodeficiencies ${ }^{13)}$.

Although plasma copper concentration is similar to that of zinc, most of the plasma copper is firmly bound to ceruloplasmin and only a small part of the copper is loosely associated with albumin $^{13)}$. Therefore, Ca-DTPA hardly combines with copper in the plasma even though copper has a higher affinity to DTPA than that of zinc $^{12)}$. In our previous studies ${ }^{3), 4)}$, Ca-DTPAinduced urinary loss of copper was estimated to be merely $1 / 70$ that of zinc, and this chelating agent did not lower plasma copper concentration. In the present experiment, however, Ca-DTPA decreased copper content in the fetal liver. This result suggests that Ca-DTPA decreased albuminbound copper in the maternal plasma without changing ceruloplasmin-bound copper concentration which accounts for the greater part of plasma copper. Ceruloplasmin-bound copper may not be concerned with placental transfer of copper. Copper is an essential element for superoxide dismutase, cytochrome c oxidase, lysyl oxidase, and several other enzymes. Anemia, bone and cardiovascular disorders, hypercholesteremia and impaired keratinization occur in copper-deficient animals $^{13)}$.

We have reported that Ca-DTPA enhances urinary excretion of manganese ${ }^{3)}$, but it could not be determined whether Ca-DTPA decreased fetal manganese content because the fetal liver contained no detectable amount of manganese. As manganese is essential for human and animals, more detailed experiments should be carried out in further studies.

$\mathrm{Zn}$-DTPA is less toxic to fetuses than $\mathrm{Ca}^{-}$ DTPA because $\mathrm{Zn}$-DTPA does not induce zinc deficiency $^{14), 15)}$. In the present experiment, $\mathrm{Zn}^{-}$ DTPA was confirmed not to induce fetal zinc depletion, but this chelating agent decreased fetal 
copper content to a degree similar to that of $\mathrm{Ca}^{-}$ DTPA. As Zn-DTPA also increases urinary excretion of copper ${ }^{5)}$, the fetal copper depletion is considered to be induced by the same mechanism as described above.

\section{Conclusion}

Ca-DTPA decreased copper and zinc contents in the fetal liver when it was injected into pregnant mice. Although $\mathrm{Zn}$-DTPA has been reported not to induce essential metal deficiency, it was confirmed to decrease copper content in the fetal liver. Because copper and zinc are essential elements for human and animals, particular attention should be given to the administration of these chelating agents, especially to pregnant women.

\section{Acknowledgment}

This research was carried out as one of common-use studies of Nishina Memorial Cyclotron Center, Japan Radioisotope Association.

\section{References}

1) NCRP : "Management of Persons Accidentally Contaminated with Radionuclides”, pp. 113-158 (1980)

2) Stevens, E., Rosoff, B., Weiner, M. and Spencer,
H. : P.S.E.B.M., 111, 235-238 (1962)

3) Sato, I., Matsusaka, N., Kobayashi, H., Sera, K., Futatsugawa, S. and Nishimura, Y. : Int. J. PIXE, 4, 59-64 (1994)

4) Sato, I., Matsusaka, N., Kobayashi, H., Suzuki, T., Sera, K., Futatsugawa, S. and Nishimura, Y. : ibid., 5, 27-32 (1995)

5) Sato, I., Matsusaka, N., Kobayashi, H., Sera, K., Futatsugawa, S. and Nishimura, Y. : ibid., 4, 269273 (1994)

6) Taylor, G. N. and Mays, C. W. : Health Phys., 35, 858-860 (1978)

7) Fisher, D. R., Calder, S. E., Mays, C. W. and Taylor, G. N. : Teratology, 14, 123 (1976)

8) Gabard, B. : Biochem. Pharmacol., 23, 901-909 (1974) '

9) Taylor, D. M. and Jones, J. D. : ibid., 21, 33133315 (1972)

10) Sera, K., Yanagisawa, T., Tsunoda, H., Futatsugawa, S., Hatakeyama, S., Saitoh, Y., Suzuki, S. and Orihara, H. : Int. J. PIXE, 2, 325-330 (1992)

11) Zylicz, E., Zablotna, R., Geisler, J. and Szot, Z. : Int. J. Radiat. Biol., 28, 125-136 (1975)

12) Hanaki, A. : Hoken Butsuri, 13, 137-145 (1978)

13) Mertz, W. ed. : "Trace Elements in Human and Animal Nutrition," 5th ed., vol. 1, pp. 301-364, vol. 2, pp. 33-87, Academic Press, Orlando (1986)

14) Brummett, E. S. and Mays, C. W. : Health Phys., 33, 624-626 (1977)

15) Fukuda, S. and Iida, H. : Hoken Butsuri, 18, 3742 (1983) 